\title{
Selective Production of Aromatic Aldehydes by Stepwise Degradation of Typical Eight Landscaping Biomass Waste: Effect of Reaction Temperature and Time
}

\author{
Siyu $\mathrm{Nie}^{1}$, Leichang $\mathrm{Cao}^{1,2, *}$ \\ ${ }^{1}$ Miami College, Henan University, Kaifeng 475004, China \\ ${ }^{2}$ Department of Environmental Science and Engineering, Fudan University, Shanghai 200433, China
}

\begin{abstract}
Greening waste presents considerable reuse potential owing to its simple organic composition. For greening waste, being simply regarded as ordinary garbage cannot adapt to the requirements of sustainable and harmless development. Resource reusing process is an inevitable trend. Utilization of urban landscape greening waste is of great significance for improving the ecological environment in urban and rural areas, building a harmonious city, increasing employment, and enhancing economic efficiency. This will be a far-reaching impact on China's economic and social sustainable development. In this work, eight typical landscape plants were selected as raw materials using the batch reactor. The concept of stepwise hydrothermal conversion and a real model with xylose, cellulose acetate (CA), and aromatic aldehyde as the target products were thereby constructed. In the third step of the stepwise conversion, the effect of reaction temperature and time in the oxidative degradation of cellulose acetate solid residues in $\mathrm{NaOH}$ solution to produce aromatic aldehyde was investigated. The optimum conditions were obtained as $175{ }^{\circ} \mathrm{C}$ and $90 \mathrm{~min}$. The yield of aromatic aldehydes in all 16 branches and leaves of cellulose acetate all reached about $20 \%$ under the optimal conditions.
\end{abstract}

\section{Background}

\subsection{Preparation of aromatic aldehydes by wet oxidative degradation of lignin}

Wet oxidation refers to the process in which organic or inorganic substances in aqueous solution or suspension are oxidized by oxidants at higher temperature and pressure $[1,2]$. The operating temperature and pressure range are $100{ }^{\circ} \mathrm{C} \sim 320{ }^{\circ} \mathrm{C}$ and $0.5 \mathrm{MPa} \sim 20 \mathrm{MPa}$ [3]. Although some studies on wet oxidation of lignin have been applied to wastewater treatment, others have focused on the production of organic acids through lignin oxidation [4,5]. However, most of the wet oxidative degradation of lignin is used to produce aromatic aldehydes, such as vanillin (VLA), syringaldehyde (SA) and p-hydroxybenzaldehyde (PHBA) [4-6]. These compounds have many applications, especially vanillin is widely used in food, cosmetics, and pharmaceutical industries as condiments and spices. However, among these products, only vanillin has been industrialized.

\subsection{Catalysis}

Catalysts are usually used in wet oxidation of lignin to improve the yield of aromatic aldehydes. These catalysts mainly include noble metals, transition metal salts and perovskite compounds [7,8]. Precious metals have a great catalytic effect. For example, compared with the oxidation process without catalyst, palladium catalyst can increase the yield of aromatic aldehydes by $10-20$ times [9]. In addition, precious metals usually exist as solid particles, which is conducive to recovery and reuse. However, due to the high cost of precious metals, the economy of commercial application is poor. Compared with precious metals, transition metal salts have lower cost and more potential for industrial application. Transition metal salts are usually water-soluble, so they are always used as homogeneous catalysts, and their isomerization can produce higher catalytic activity. $\mathrm{Cu}^{2+}$ is considered to be the most effective homogeneous catalyst [10]. One of the problems affecting the industrial application of homogeneous catalysts is that it is difficult to recover them. For example, about $40 \%$ of the homogeneous catalyst phosphomolybdic acid is lost as the reaction medium when reaching the final process. In addition, these homogeneous transition metal salts can lead to the secondary pollution of the discharged water to the environment. Deng et al. [11-16] has made great contributions to the research of perovskite oxide catalysts. They have found that these perovskite oxide catalysts exhibit high activity and stability in the wet oxidation of lignin. However, compared with transition metal catalysts, these perovskite oxides require additional sol-gel process.

\footnotetext{
* Corresponding author: clch666@163.com
} 


\subsection{Effect of reaction conditions}

The degradation of lignin to aromatic aldehydes is a complex reaction. Syringaldehyde, vanillin and $\mathrm{p}$ hydroxybenzaldehyde are intermediates of lignin wet oxidation process, which are derived from three basic structural units of lignin. These aldehydes can be formed under appropriate conditions because the activation energies of these aldehydes are much higher than those of lignin. The initial degradation reaction of lignin is faster because of its lower activation energy $(4426 \mathrm{~kJ} / \mathrm{mol})$ [10]. $100-190{ }^{\circ} \mathrm{C}$ is the commonly used suitable temperature range. In addition, the molecular weight of lignin has a great influence on the preparation of vanillin $[17,18]$, and lignin with low molecular weight usually has higher vanillin yield.

\section{Experimental}

\subsection{Pretreatment of greening waste}

The discarded pine branches were collected from Handan Road Campus of Fudan University in Shanghai, China. After the raw branches and leaves were just trimmed by the workers are collected, they are dried in an oven at $105{ }^{\circ} \mathrm{C}$ for 8 hours, and then mechanically crushed through a 40 mesh sieve, and the screened samples are kept for standby.

\subsection{Catalytic oxidation of cellulose acetate solid residue}

The lignin conversion rate was calculated according to the lignin mass (m) in the original cellulose acetate solid residue. The mass weight of aromatic aldehydes in the extracted liquid was determined by GC-MS external standard method (e.g., Fig. 1, 2, 3 and 4), and the yield of aromatic aldehyde was finally calculated based on the weight of cellulose acetate residues.

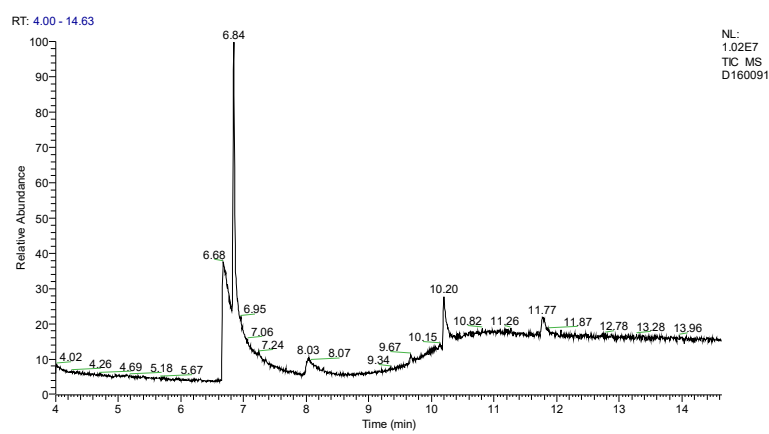

Fig. 1. TIC spectrum of cellulose acetate solid residue catalytic oxidation products (conditions: $2.0 \mathrm{~mol} / 1 \mathrm{NaOH}$ solution 100.0ml, $\left.1.5 \mathrm{MPa}, 150{ }^{\circ} \mathrm{C}, 90 \mathrm{~min}\right)$.

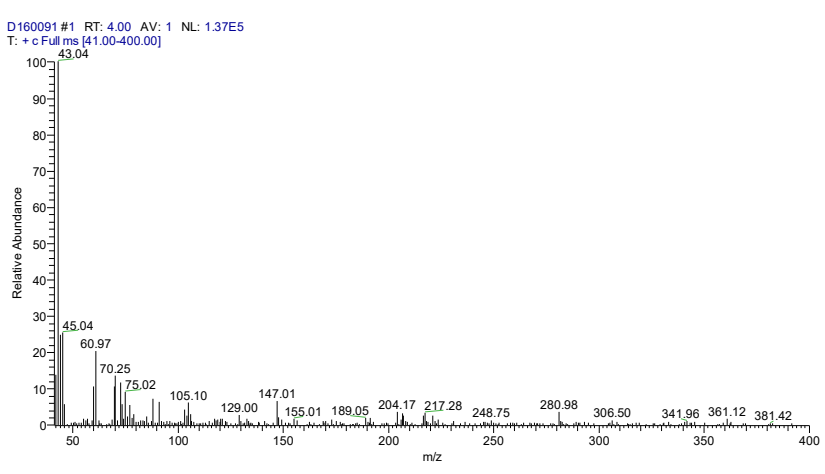

Fig. 2. Mass spectrogram of cellulose acetate solid residue catalytic oxidation products (conditions: $2.0 \mathrm{~mol} / 1 \mathrm{NaOH}$ solution $\left.100.0 \mathrm{ml}, 1.5 \mathrm{MPa}, 150{ }^{\circ} \mathrm{C}, 90 \mathrm{~min}\right)$.

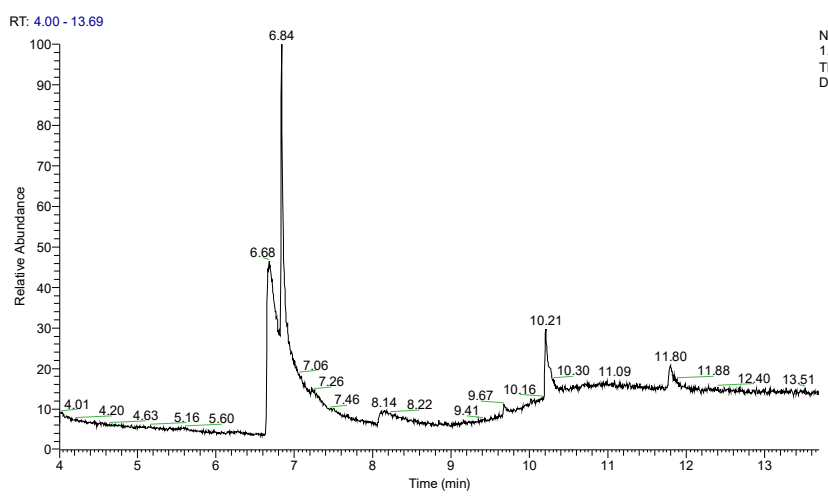

Fig. 3. TIC spectrum of cellulose acetate solid residue catalytic oxidation products (conditions: $2.0 \mathrm{~mol} / 1 \mathrm{NaOH}$ solution $\left.100.0 \mathrm{ml}, 1.5 \mathrm{MPa}, 125^{\circ} \mathrm{C}, 90 \mathrm{~min}\right)$.

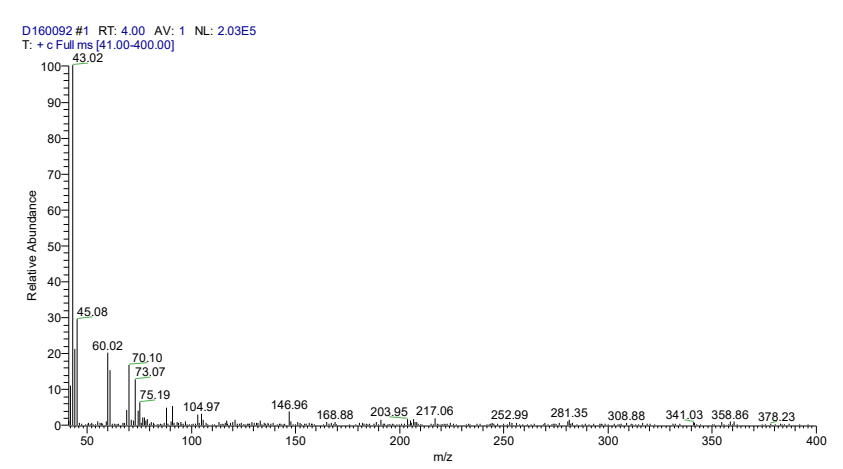

Fig. 4. Mass spectrogram of cellulose acetate solid residue catalytic oxidation products (conditions: $2.0 \mathrm{~mol} / 1 \mathrm{NaOH}$ solution $\left.100.0 \mathrm{ml}, 1.5 \mathrm{MPa}, 125^{\circ} \mathrm{C}, 90 \mathrm{~min}\right)$.

\section{Results and Discussion}

\subsection{Effect of reaction temperature}

Table 1 shows the effects of other conditions and different reaction temperatures on the oxidative degradation of cellulose acetate to aromatic aldehydes.

Table 1. Effect of reaction temperature on catalytic oxidation of cellulose acetate solid residue (Pine branch).

\begin{tabular}{|c|c|c|c|c|c|}
\hline $\begin{array}{c}\text { Temper } \\
\text { ature } \\
\left({ }^{\circ} \mathrm{C}\right)\end{array}$ & $\begin{array}{c}\text { VLA } \\
(\mathrm{g})\end{array}$ & $\begin{array}{c}\text { SA } \\
(\mathrm{g})\end{array}$ & $\begin{array}{c}\text { PHBA } \\
(\mathrm{g})\end{array}$ & $\begin{array}{c}\text { Lignin } \\
\text { Conversion } \\
\text { rate }(\%)\end{array}$ & $\begin{array}{c}\text { Total } \\
\text { Yield } \\
(\%)\end{array}$ \\
\hline
\end{tabular}




\begin{tabular}{|c|c|c|c|c|c|}
\hline 125 & 0.021 & 0.010 & 0.006 & 60.5 & 7.4 \\
\hline 150 & 0.034 & 0.015 & 0.011 & 88.2 & 12.0 \\
\hline 175 & 0.065 & 0.032 & 0.022 & 100 & 23.8 \\
\hline 200 & 0.051 & 0.034 & 0.020 & 100 & 21.0 \\
\hline
\end{tabular}

According to the data in the table above, the conversion and yield of lignin are relatively low at lower temperature. When the temperature was too high, the conversion of lignin reached $100 \%$, but the yield was lower than that at $175^{\circ} \mathrm{C}$. This indicates that temperature can significantly affect the wet oxidation reaction of cellulose acetate solid residues, and proper temperature can make the conversion of lignin and the yield of aromatic aldehydes reach the maximum.

\subsection{Effect of reaction time}

Table 2 shows the effect of reaction time on the preparation of aromatic acids by oxidative degradation of cellulose acetate. It can be seen from the table that when the reaction temperature is $90 \mathrm{~min}$, the conversion of lignin and the yield of aromatic aldehydes reach the maximum value. If the reaction time is too long, the side reaction will be increased and the yield of aromatic aldehyde will be reduced [17].

Table 2. Effect of reaction time on catalytic oxidation of cellulose acetate solid residue (Pine branch).

\begin{tabular}{|c|c|c|c|c|c|}
\hline $\begin{array}{c}\text { Time } \\
(\mathrm{min})\end{array}$ & $\begin{array}{c}\text { VLA } \\
(\mathrm{g})\end{array}$ & $\begin{array}{c}\text { SA } \\
(\mathrm{g})\end{array}$ & $\begin{array}{c}\text { PHBA } \\
(\mathrm{g})\end{array}$ & $\begin{array}{c}\text { Lignin } \\
\text { Conversion } \\
\text { rate }(\%)\end{array}$ & $\begin{array}{c}\text { Total } \\
\text { Yield } \\
(\%)\end{array}$ \\
\hline 30 & 0.023 & 0.013 & 0.008 & 67.3 & 8.8 \\
\hline 60 & 0.034 & 0.018 & 0.010 & 86.5 & 12.4 \\
\hline 90 & 0.065 & 0.032 & 0.022 & 100 & 23.8 \\
\hline 120 & 0.043 & 0.021 & 0.015 & 100 & 15.8 \\
\hline
\end{tabular}

\subsection{Yield of residual aromatic aldehydes from cellulose acetate of other greening wastes}

The acetylation of other greening wastes activated by phosphoric acid (conditions: temperature $150{ }^{\circ} \mathrm{C}$, time $1.8 \mathrm{~h}$, liquid-solid ratio $8 \mathrm{ml} / \mathrm{g}$, phosphoric acid concentration $1.67 \%$ ) was carried out (conditions: acetic acid/acetic anhydride $=18 \mathrm{ml} / 18 \mathrm{ml}, 3 \mathrm{~g}$ solid residue, $60{ }^{\circ} \mathrm{C}, 4 \mathrm{~h}, 300 \mathrm{rpm}$ ), and then the obtained solid residues were subjected to the optimized catalytic oxidation conditions (cellulose acetate solid residue 3.0 g). The results are listed in Table 3.

Table 3. Yields of aromatic aldehydes from cellulose acetate solid residues of typical landscaping waste (wt\%).

\begin{tabular}{|c|c|c|}
\hline Catalyst & Branches & Leaves \\
\hline Pine needle & 23.8 & 25.3 \\
\hline Cupressus funebris & 21.8 & 24.0 \\
\hline Platanus & 21.1 & 23.7 \\
\hline $\begin{array}{c}\text { Cinnamomum } \\
\text { camphora }\end{array}$ & 19.5 & 21.8 \\
\hline Pittosporum tobira & 23.2 & 24.4 \\
\hline
\end{tabular}

\begin{tabular}{|c|c|c|}
\hline $\begin{array}{c}\text { Distylium } \\
\text { racemosum }\end{array}$ & 22.7 & 23.3 \\
\hline $\begin{array}{c}\text { Viburnum } \\
\text { odoratissinum }\end{array}$ & 20.6 & 21.8 \\
\hline Salix babylonica & 17.3 & 19.7 \\
\hline
\end{tabular}

As shown in Table 3, the yield of aromatic aldehydes in all eight branches and leaves reached about $20 \%$, and the yield of aromatic aldehydes in leaves was higher than that in branches. The average contents of cellulose, hemicellulose and lignin in leaves are lower than those in branches, which is consistent with the plant biological differences between branches and leaves. Cellulose, hemicellulose and lignin exist in the cell wall of plants, and their contents vary with different parts of the plant [19]. Cellulose is dispersed in the plant cell wall in the form of microcrystalline filaments. Hemicellulose and lignin play a filling role, and act as a skeleton to connect the crystalline filaments $[7,20]$. Because the cell walls of branches are more lignified, the branches usually contain more and stronger lignin and tighter lignin skeletons than leaves. Therefore, this may be the reason why the yield of aromatic aldehydes in branches is lower than that in leaves.

\section{Conclusions}

The oxidation degradation of cellulose acetate in $\mathrm{NaOH}$ solution to produce aromatic aldehydes was investigated by single factor test. The optimum reaction temperature was $175^{\circ} \mathrm{C}$ and the reaction time was $90 \mathrm{~min}$. Under the optimal conditions, the yield of aromatic aldehydes in all eight branches and leaves was about $20 \%$. In addition, the yield of aromatic aldehydes in leaves was higher than that in branches.

\section{Acknowledgement}

The authors are thankful for the financial support from the National Key Technology Support Program (No. 2015BAD15B06). The authors are also grateful for the provision of a scholarship by Shanghai Tongji Gao Tingyao Environmental Science \& Technology Development Foundation. Lastly, the authors thank anonymous reviewers for fruitful suggestions.

\section{References}

1. J.C. Colmenares, W.Y. Ouyang, M. Ojeda, E. Kuna, O. Chernyayeva, D. Lisovytskiy, S. De, R. Luque, A.M. Balu, Appl Catal B-Environ, 183 (2016)

2. Y. Yang, X.R. Li, R.R. Shen, Z.R. Liu, D.S. Ji, Y.S. Wang, J Environ Sci, 89 (2020)

3. S. Dabral, M. Turberg, A. Wanninger, C. Bolm, J.G. Hernandez, Molecules, 22 (2017)

4. M.S. Kamal, S.A. Razzak, M.M. Hossain, Atmos Environ, 140 (2016)

5. Q.Q. Xu, Z.J. Zheng, L.H. Zou, C. Zhang, F. Yang, K.J. Zhou, J. Ouyang, Bioproc Biosyst Eng, 43 (2020)

6. V.F. Wendisch, Y. Kim, J.H. Lee, Curr Opin Green Sust, 14 (2018) 
7. C.G. Liu, P. Zhang, Y.F. Wang, B. Yang, J.N. Shu, Environ Sci Technol, 46 (2012)

8. M. Moliner, Dalton T, 43 (2014)

9. L. Hdidou, K. Khallouk, A. Solhy, B. Manoun, A. Oukarroum, A. Barakat, Catal Sci Technol, 8 (2018)

10. H.E.P. Salonen, C.P.A. Mecke, M.I. Karjomaa, P.M. Joensuu, A.M.P. Koskinen, Chemistryselect, 3 (2018)

11. [11] H.B. Deng, L. Lin, S.J. Liu, Energ Fuel, 24 (2010)

12. H.B. Deng, L. Lin, Y. Sun, C.S. Pang, J.P. Zhuang, P.K. Ouyang, J.J. Li, Chinese J Catal, 29 (2008)

13. H.B. Deng, L. Lin, Y. Sun, C.S. Pang, J.P. Zhuang, P.K. Ouyang, J.J. Li, S.J. Liu, Energ Fuel, 23 (2009)

14. H.B. Deng, L. Lin, Y. Sun, C.S. Pang, J.P. Zhuang, P.K. Ouyang, Z.J. Li, S.J. Liu, Catal Lett, 126 (2008)

15. H.B. Deng, H. Zhang, Z.L. Wu, X.Z. Tian, X. Jiang, W.M. Guo, Bioresources, 15 (2020)

16. J.H. Zhang, H.B. Deng, L. Lin, Molecules, 14 (2009)

17. Y. Luo, V.K. Guda, E. Hassan, P.H. Steele, B. Mitchell, F. Yu, Energ Convers Manage, 112 (2016)

18. J. Mottweiler, M. Puche, C. Rauber, T. Schmidt, P. Concepcion, A. Corma, C. Bolm, Chemsuschem, 8 (2015)

19. J.D. Smith, H. Kinney, C. Anastasio, Atmos Environ, $126(2016)$

20. Y.Q. Jia, Y.Q. Wen, X. Han, J. Qi, Z.H. Liu, S.M. Zhang, G. Li, Catal Sci Technol, 8 (2018) 